\section{Non-isotopic and sensitive method for diagnosis of maternally-inherited diabetes and deafness}

\section{Dear Sir,}

An $A$ to $G$ transition mutation at nucleotide 3243 of the tRNA ${ }^{\text {Leu }}{ }^{U R}$ of the mitochondrial DNA (mt DNA), was recently reported in NIDDM patients characterized by maternal inheritance and associated deafness (MIDD) [1-2], with an estimated prevalence of $1-2 \%$ [ 3 and unpublished results]. The same mutation is also found in the clinically different MELAS syndrome (mitochondrial myopathy, encephalopathy, lactic acidosis and stroke-like episodes) [4-5]. MIDD and MELAS present in cells, including lymphocytes, mutant mitochondrial DNA and wild type DNA. However, heteroplasmy levels vary according to the tissue and to the individual carrying the same defect. Classic screening for such a mutation is based on an isotopic polymerase chain reaction (PCR) of the region, followed by a specific digestion. The mutation creates an Apal restriction site which is never found in control subjects. However, this technique suffers from low sensitivity (particularly when the rate of heteroplasmy in blood cells is low) and consequently requires at least a week of autoradiography to distinguish positive from negative results.

Therefore, we have established a non-isotopic, quick and sensitive method to detect this mutation in mt DNA using the Phar-

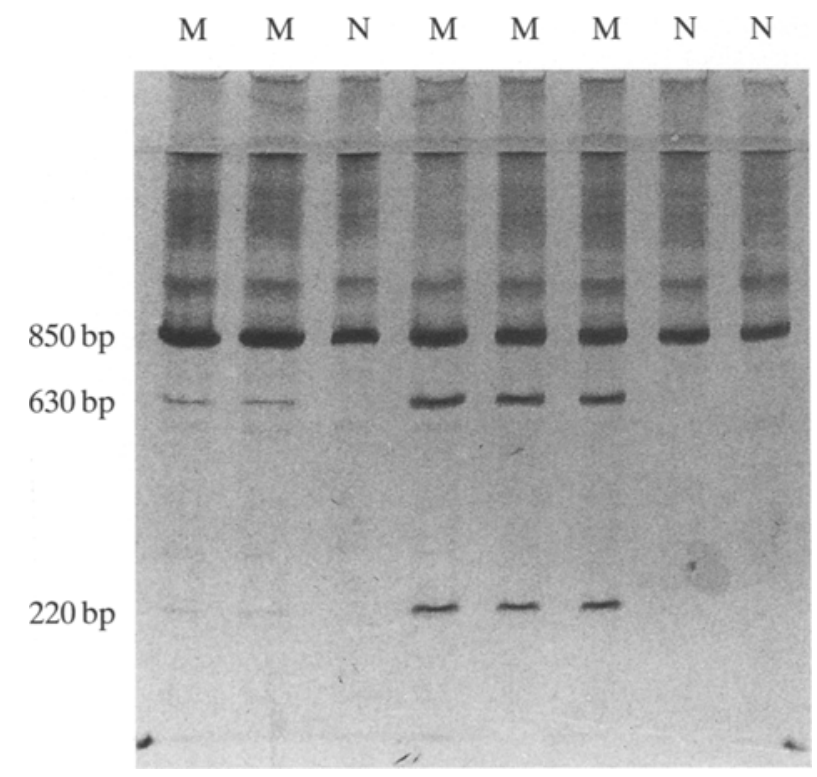

Fig. 1. See text

Corresponding author: Dr. Ph. Froguel, Human Polymorphism Study Center, Fondation Jean Dausset - CEPH, 27 rue Juliette Dodu, F-75010 Paris, France macia PhastSystem. PCR was performed on a Perkin Elmer 600 thermal cycler (Perkin Elmer, Branchburg, USA) using $200 \mathrm{ng}$ genomic DNA, extracted from lymphocytes, $0.2 \mathrm{mmol} / \mathrm{l}$ $\mathrm{dNTP}, 50 \mathrm{ng}$ of each primers A and B (A: CAC TTG TTC CTT AAA TAG GG and B: AGC GAA GGG TTG TAG TAG CC) and 1 unit Ta polymerase (Perkin Elmer). Cycling conditions were: a first denaturation at $94^{\circ} \mathrm{C}$ for 5 minthen 30 cycles of $30 \mathrm{~s}$ at $94^{\circ} \mathrm{C}, 56^{\circ} \mathrm{C}$ and $72^{\circ} \mathrm{C}$, and a final extension at $72^{\circ} \mathrm{C}$ for $6 \mathrm{~min}$. PCR products of 850 bp were digested for $2 \mathrm{~h}$ at $25^{\circ} \mathrm{C}$ with the restriction enzyme ApaI (Biolabs, Beverly, USA). After a pre-run of the non-denaturing pre-cast polyacrylamide gels $(12.5 \%)$ (Pharmacia, Uppsala, Sweden) at $200 \mathrm{Vh}$, samples were automatically loaded and run at $4^{\circ} \mathrm{C}$ for $100 \mathrm{Vh}$. Gels were then transferred in the coloration unit on the PhastSystem, silver stained and dried. A gel with eight different DNAs is presented (Fig.1), five of them carrying the mutation. The presence of the $A->G$ mutation in patient's DNA is detected by two additional bands of 630 and 220 bp after the ApaI digestion (lanes indicated by M), as compared to wild type mt DNA for which a unique band of $850 \mathrm{bp}$ is detected (lanes indicated by N).

The use of the PhastSystem enabled a very sensitive and reproducible detection of this mutation and avoided the use of radioelements. Moreover, with this system, we were able to detect the presence of a mutation in $2 \mathrm{~h}$.

Using this technique, we screened NIDDM patients and families referred to us by clinicians, for the presence of the mutation. Patients were either affected by diabetes associated with deafness or they belonged to a family where the mutation had been detected previously. We identified the mutation in 24 NIDDM patients from seven different families.

In conclusion, this test should be very helpful to improve diagnosis of patients affected with maternally-inherited diabetes associated with deafness. The same assay can also be used to recognize individuals carrying this mutation and who are at risk of developing either MIDD or the MELAS syndrome.

\section{H. Blanché, Ph.Froguel, J. Dausset, D. Cohen, N. Cohen}

\section{References}

1. Reardon W, Ross RJM, Sweeney MG et al. (1992) Diabetes mellitus associated with a pathogenic point mutation in mitochondrial DNA. Lancet 340: 1376-1379

2. Van den Ouweland JMW, Lemkes HHPJ, Ruitenbeek W et al. (1992) Mutation in mitochondrial tRNA ${ }^{\text {Leu(UUR) }}$ gene in a large pedigree with maternally transmitted type II diabetes mellitus and deafness. Nature Genetics 1: 368-371

3. Vionnet N, Passa Ph, Froguel Ph (1993) Prevalence of mitochondrial gene mutations in families with diabetes mellitus. Lancet 342: 1429-1430

4. Goto YI, Nonaka I, Horai S (1990) A mutation in the tRNALeu(UUR) gene is associated with the MELAS subgroup of mitochondrial encephalomyopathies. Nature 348: 651-653

5. Hammans SR, Sweeney MG, Brockington M, MorganHugues JA, Harding AE (1991) Mitochondrial encephalopathies: molecular genetic diagnosis from blood samples. Lancet 337: 1311-1313 